\title{
A Comparative Analysis of the Poetics of Anger in John Osborne's Look Back in Anger and Femi Osofisan's The Chattering and the Song
}

\author{
Bosede Funke Afolayan (Ph.D.) \\ Department of English,University of Lagos, Nigeria \\ bafolayan@unilag.edu.ng
}

\begin{abstract}
Anger is a basic human emotion which has a force for constructive or destructive ends. Its expression in any circumstance can be a trigger for a desire to change a prevailing situation. In all cases, anger is a fundamental component of art. This study examines the use of anger in Osborne's Look Back in Anger and Osofisan's The Chattering and the Song. Osborne and Osofisan are two writers who are very anxious to change their societies through their art. In spite of differences in their origin (Osborne was a Briton while Osofisan is a Nigerian), they wrote at a time of certain social and political upheavals in their countries. They also share similar concerns and attitude towards art. My focus in this paper is on the early plays of Osborne and Osofisan where anger is strongest and where their artistic triumph is most poignant. Working within the formalist approach, the paper reveals that in Osborne and Osofisan, extreme anger is both material and style and is what marks their art out. The reification by the intellect provides a potent instrument for investigating society. Anger becomes the point of departure for their art, it is not mere hysterics but a cerebral one and it is the motivating force for their writings.
\end{abstract}

Key words: Anger, British drama, African drama, John Osborne, Femi Osofisan, Literary history.

\section{Introduction}

This study is a comparative analysis of Osborne's Look Back in anger and Osofisan's The Chattering and the Song, an English and a Nigerian play whose aim is to reform society by drawing attention to its ills. Like all comparative studies where the influence of a foreign author on a local one is extracted, this study is more interested in exploring certain interconnectedness in terms of theme, form and the context of the plays. The work is interdisciplinary because it takes concepts from psychology, sociology, literature and culture in exploring its concerns. The paper is based on a pivotal idea of anger that is germane and integral to the art of these two writers from disparate continents, and it focuses on their utilization of anger as an emotional construct.

Since it discusses how anger is replicated in the selected plays, the paper attempts to demonstrate how this term is expressed in the theory and practice of playwriting of these two writers. Anger is revealed in their intense concern and disenchantment with the society. It informs their 
consciousness, conditions their creative impulse, is demonstrated in the speeches of the protagonists and it is a major thematic preoccupation of the plays. The paper is more interested, however, in establishing that the portraiture of anger in their art does not whittle down their artistry, contrary to assumptions that their reformist zeal tends to overwhelm the literariness. The methodological procedure adopted is to scrutinise and interpret the speeches of key characters while relying extensively on earlier studies to demonstrate our points.

\section{Conceptualising Anger}

A central concept in this paper is anger and it needs to be properly conceptualised. Anger is generally believed to be a destructive, unpleasant, immature, aggressive, hostile, anti-social, impulsive, abominable and an indecent emotion. However, as a much-maligned emotion, it has its positive aspect as an unavoidable fact of life and a feature of human interaction. This seemingly ignoble emotion is also a weapon of self-assertion since it is excited by a sense of wrong. People are bound to be angry when mistreated or when others refuse to obey social laws. Anger is also a sociological and philosophical issue that can be triggered by social injustices such as anger at racism and sexism. It is a basic political element that opens the way to new ideas and new ways of seeing things. It is in line with the above that I utilise the concept in understanding the plays of Osborne and Osofisan.

Harriet Goldhor-Lerner in her book; A Dance of Anger is critical to this analysis. She states that "Anger is a signal .... It may be a message that we are being hurt, that our rights are being violated; that our needs or wants are not being adequately met or simply that something is not right." (1) In other words, anger is a product of social interaction and to some extent, a useful response to frustrations. It is, thus, not a totally negative emotion.

This view aligns with Carol Tavris position that:

Anger is not a disease with a single cause, it is a process, a transaction, a way of communicating. With the possible exception of anger cause by organic abnormalities, most angry episodes are social events. They assume meaning only in terms of the social contract between participants. (162)

Tracing the use of anger in playwriting, I note that the drama of anger has its precursor in Jarry Alfred's Ubu Roi in 1896. The play's use of harsh words and blunt and verbal abuse has no antecedent. It has also been copied by Wole Soyinka in the dramatization of the sadistic years of the late Sanni Abacha of Nigeria in King Baabu. The vitriolic and acerbic use of words and grotesque depiction of Baabu and Maariya is reminiscent only of Ubu in Jarry Alfred's play.

\section{Background of Study}

As a member of society, a writer is confronted with myriads of social, economic and political issues and these in most cases, engage his/her attention. He reacts to these tensions in different ways: he could escape from the scene of grave corruption and moral ineptitude by resorting to dreams in his writings or he could, in disgust and great moral outrage, "take up arms" through his 
art and lash out against societal ills in overt terms, employing angry language and satire with the sole aim of shocking the society to an awareness of the ills. My concern in this paper is with the latter writers who are greatly irked by social and political circumstances of their times and employ their art as instruments of social criticism and social engineering.

On the English stage, no playwright before John Osborne has been so vituperative in his language as him. From Shakespeare to Ben Jonson, Richard Sheridan, Oliver Goldsmith, no dramatists engaged the society frontally like Osborne. The drama before him was largely conformist, pandering to the taste of the society. even in the latter part of the nineteen century and the beginning of the twentieth century when drama in Europe and America emerged as an instrument for the discussion of serious issues in both form and content. Writers such as Henrik Ibsen in Norway, Strindberg in Sweden, Pirandello in Italy, Arthur Miller in America and Anton Chekhov in Russia blazed the trail. Of note in Britain was the work of George Bernard Shaw who was the first English dramatist to use his plays for societal awakening.

The events after the Second World War of 1939-1945 demanded a new type of drama. The end of the war seemed to mark the beginning of a new era for drama. Post-war Britain was a period of serious social and political upheavals, especially with the breakdown of the class system. It was a society where so much was expected from those in authority but nothing was forthcoming. This ultimately led to disillusionment and despair. However, there was liberalisation in education which made many people in the middle and working classes to go to the university but there were no jobs for the graduates (Ward, 17). The enormous problems of this era invariably provided the basis for the new dramatic efflorescence championed by new playwrights and writers such as John Osborne, Ann Jellicoe, Kingsley Amis, C. Wilson, Alan Sillitoe and John Arden. These writers were young and felt more keenly the deleterious effects of the malaise in the society and they brazenly used their art to encapsulate the despair and negotiate social change. They were not subtle but belligerent and vitriolic, left-winged and irreverent.

John Osborne was a leading light of this era. As a member of the lower middle class, he wrote plays that dealt with class struggles, with passion. He was an actor, playwright, theatre and film director and he later became a Lord in the British Upper House, a fact which should have changed his non-conformist attitude towards the aristocracy in particular. Osborne died in 1994. His plays include Look Back in Anger, The Entertainer, Luther, A Patriot for Me, Time Present and Inadmissible Evidence.

His philosophy of writing is expressed in the following words: "I want to make people feel, to give them a lesson in feeling. They can think afterwards ...." (Banham, 30). This overtly sensitivity earned him and others, mentioned earlier the term, "Angry Young Men"; a sobriquet which was a catch-phrase in Britain in the middle and late 1956. It referred to young writers who were vocal in their depiction of the disillusionment and dissatisfaction of young people. The term, according to Kenneth Allsop suggests many things which include "irreverence, stridency, impatience with tradition, vigour, vulgarity, sulky resentment against the cultivated ...” (Allsop 19). Look Back in 
Anger helped to express the mind of young people in Britain and began the trend. John Russell Taylor in his book Anger and After helped to shape the notion of the term:

8 May 1956 marks the breakthrough of a new drama into the British theatre, and Osborne himself remains ... the first of the "Angry Young Men" and arguably the biggest shock to the system of British theatre since the advent of Shaw. (Taylor 37)

George Bernard Shaw was a shock to the British people in writing plays such as Mrs Warren's Profession, Widowers' Houses and others plays he referred to as "Plays Unpleasant". For instance, he laid the blame for women going into prostitution squarely at the door of the society who could not provide job opportunities for its women and on male licentiousness. This was a big shock at that time. The shock is however, greater in Osborne's use of language and irreverence in Look Back in Anger as we shall see later.

On the Nigerian stage, no playwright has expressed so much anger and dissatisfaction as Femi Osofisan. Before him are the first-generation dramatists such as Wole Soyinka, J. P. ClarkBekederemo, Zulu Sofola and Ola Rotimi who were conservative in their vision, pandering to traditional culture and sometimes, imitative of the West in order to prove that their works were of equal quality and worth with those of the western writers.

However, with the Nigerian civil war of 1967-1970 and its attendant social and economic problems, new writers emerged. The oil boom after the war created a sharp gap between the rich and the poor. These new writers saw a lot of problems in the society and reacted to these issues by imbibing the Marxist aesthetics and philosophy as alternative to the problems. These writers include Femi Osofisan, Kole Omotosho, Bode Sowande, Wale Ogunyemi, and Tess Onwueme. They are classified as second-generation dramatists in Nigeria (Yemi Ogunbiyi, 36 and Olu Obafemi,168). Their attitude to societal ills is revolutionary and the aim is to change society through their art. Femi Osofisan occupies a significant place in this group as the most strident and most prolific.

Femi Osofisan is a university lecturer, theatre director, an administrator, a novelist, poet and essayist. He has written about fifty plays and some of them are Morountodun, The Chattering and the Song, Farewell to a Cannibal Rage, Women of Owu, Once Upon Four Robbers and Birthdays Are Not for Dying. In deviating sharply from the concerns of the older generation, because the times were different, he embraced revolution against the romantic explorations of the gods in Soyinka and Clark. He became belligerent and vociferous in the treatment of societal ills. In his essay, "The Alternative Tradition: A Survey of Nigerian Literature after the War", Osofisan submits that:

The older writers represented a watershed, in both the socio-historical and the purely aesthetic aspects of artistic expression, and it was a watershed from which we had to depart in order to keep our rendezvous with history. Muted now are the lyrical clairvoyant cadences of Okigbo, the raw, inchoate passions of Soyinka and his challenging esotericism; 
and muted also Achebe's sedate, serious concern for the often-tragic mutation in social culture. These voices, together with their unending mythopoetic narcissism had to be left behind, because when all is said and done, behind their genuine human attitude there was always a plea for a reactionary or simply impracticable idealist utopia, engaged in false maze of a tragic cycle. (Osofisan 783)

To achieve a complete breakaway from the reactionary and tragic visions of the older generation, Osofisan embraced a revolutionary posture. In his own words on his philosophy of writing:

To use the pen we had, our zeal and our eloquence- to awaken in our people the song of liberation. With our writing, we would wash the stigma away, the stigma of inferiority, rouse our dormant energies, unmask the pest and traitor among us, preach the positive sermons. Our works would be a weapon in the struggle to bring our country to the foremost ranks of modern nations. Our songs would call for radical alternative. (Osofisan 1987, 6)

Thus, the same attitude to societal ills noted in Osborne is inherent in Osofisan. Their responses to writers before them is another common ground. How this attitude is played out in their creative work forms the body of the next section.

\section{Anger in Osborne's Look Back in Anger}

The plot of Look Back in Anger is a simple and conventional one. On the surface, it tells the story of an estranged marriage. A story of two people from two different classes of society living together as husband and wife. The relationship already evokes feelings of conflict, resentments, misunderstanding and sometimes, inferiority complex. In the play, the wife leaves and returns to continue their unrealistic game of "bear and squirrel that begins the play. In this way, the play is a "piece of straight-forward dramatic realism" (Martin Banham, 12). However, in this simple story of a failed marriage is built the issues of class, alienation and the socio-political circumstances of the Britain of 1956.

As earlier stated, the plays of Terrence Rattigan, Christopher Fry and T. S. Eliot, prior to 1956, showed elaborate and sometimes symbolic settings and the plays were well-made plays and drawing - room comedies. It is significant to note that all the actions in Look Back in Anger take place in one set- the Porters' one-room flat in Midlands. This bare setting is at once a shock to its audience and a pointer to the acute housing problem of the time. Stephen Lacey avers that: "The realism of a set like this asks to be judged not only in relation to the observable social reality beyond the stage but also against other kinds of theatre; in both senses the play was a considered provocation." (29)

The play opens with Jimmy and Cliff on Sunday evening reading the newspapers with Alison at the ironing board. The ironing board is in itself a domestic labour that is absent on the stage of a well-made play. This was a revolution as the audience was invited to see a world that was sordid (Banham 12). 
It is in Jimmy's speech, however, that the audience is introduced to the class system in Britain. Jimmy is angry that the newspapers seem to be divided into the "high and mighty and the posh ones". A deliberate act to exclude the poor and common people by writing half of the news in French, in a language that only the upper class can understand. He attacks the reviews for being the same even with different books. To him, nothing changes. This division already prepares us for the social barriers that exist in the society. By lashing out at this injustice, Jimmy becomes the "representative of a generation determined to destroy this kind of injustice (Alan Carter 23). It is this kind of intellectual snobbery that Jimmy fights in the play.

Anger is remarkably present in Osborne's play. It is emblazoned in the title and it colours his criticism of his society seen in the various attacks on class, the Establishment and religion. Acknowledged as Osborne's first and famous work, it launched him into stardom. Osborne's anger at the various injustices in the society is championed by the major character, Jimmy, who articulates the disillusionment of the post-war youth in Britain. Before now, Britain was regarded as a superpower, but with the decline in her empire by the colonies' declarations of independence, Britain lost most of her territories and this had a great effect on her social and economic life.

The year 1956 itself was rife for "agitation or disillusionment". John Russell Taylor in the book John Osborne: Look Back in Anger provides the context for the unrest in Britain over nuclear disarmament, the revolt in Hungary, the Suez Canal debacle where Britain was humiliated and the illusion of Britain ruling the world was destroyed (Taylor 14). For instance, Egypt had gone on to nationalise the Suez Canal which at that time was controlled by Britain. Britain and France mobilised forces to wage war against Egypt and could have carried it through but for the intervention of the United States. Britain lost face. The people's self-esteem was affected and the image of Britain as a superpower dimmed. Osborne was one of the writers who addressed Britain's fortunes at this time.

Even within Britain, there was unrest because young people who were the major beneficiaries of the mass tertiary education of 1944 could not secure jobs after their education. Such is the case of Jimmy who with his university education keeps a "sweet stall". Jimmy is a representative of his age and it is in him, that the anger against the way the Establishment has treated them is greatly reflected. The play is thus about anger. Anger is reflected in the title and it remains the major thematic thrust of the play. Carter observes that: 'Look Back in Anger is not a play about anger; it is about feelings, about despair...' (131) What is anger, if not an emotion that reflects strong feelings? The anger here is not "malicious" but the obverse of which is love. It is a call for greater commitment to the issues of the lower class. Indeed, Jimmy Porter's verbal onslaughts stem from despair, but they carry his deep love for a society that refuses to show love to its lower classes. Jimmy Porter's anger also is a product of his frustration with his society. He lives in a society that enables him to have an upper- class education but denies him an employment that correlates with his education. He has tried many jobs before settling down to selling sweets. 
Jimmy's wife also contributes to his frustration by her nonchalant attitude. Alison knows exactly what Jimmy requires from her but she is unwilling to make adjustments. In frustration, he rages: "Nothing I could do would provoke her..." (19). Jimmy, in anger, laments Alison's inaction and her "passivity." All he craves for (from her) is some enthusiasm. Jimmy says of her: "She's a great one for getting used to things..." (16). Instead of reacting to the issue at hand, Alison just flows with it. It is this inability to communicate that leads to his frustration. Jimmy's anger also has a root. He watched his father die at the age of ten. To him, "anyone who has never watched someone die is suffering from a bad case of virginity. (57)

Osborne's disgust for religion which translates to anger is also reflected in the play. The play opens on a Sunday evening. Jimmy Porter later complains about the insistent ringing of the church bells. The "Bishop of Bromley" is attacked for his "vaguery." And Sunday, itself, is seen as a "depressing day."

God, how I hate Sundays! It's always so depressing, always the same. We never seem to get any further, do we? Always the same ritual. Reading the papers, drinking tea, ironing. A few more hours, and another week gone. Our youth is skipping away.... (1415)

According to Carter, Osborne's anger is against the established church and its servants. His anger stems from the fact that the church does not address the 'problems of today'. Therefore, Jimmy Porter's anger on the church is a call for 'real religion not less' (3). Again, Jimmy Porter also taunts Helena into inviting the parson over for tea in the hope that some of his 'spiritual beefcake' would make a man of him. Hear him:

Jimmy: ... should I go in for this moral weightlifting and get myself some over developed muscle? I was a liberal skinny weakling. I too was afraid to strip down to my soul, but now everybody looks at my superb physique in envy... (79).

To reinforce his attack on religion, Jimmy cites the uncaring attitude of religious people:

Did you read about the woman who went to the mass meeting of a certain American evangelist at Earl's court? She went forward, to declare herself for love or whatever it is, and, in the rush of converts to get to the front, she broke four ribs and got kicked in the head. She was yelling her head off in agony, but with 50,000 people putting all they'd got into "Onward Christian Soldiers", nobody even_knew she was there. (14 Emphasis mine)

Behind this mask of anger is Jimmy Porter's plea for more care, more commitment and honest responses from people. The attack on religion is also a central concern in The Entertainer and Luther.

His keen and deep love for society makes Jimmy Porter a very lonely man, despite his talkative nature. The theme of loneliness is exemplified in different references to isolation in Look Back in Anger. Jimmy Porter is an extremely sensitive person who demands greater reaction from his 
listeners - this is what his angry outbursts seem to call for. He seeks more involvement from his wife especially, and when he gets none, he becomes agitated and offensive. We note this right from the opening of the play. He says to Alison: "You can talk, can't you? You can express an opinion; or does the White Woman's burden make it impossible to think?” (11).

Jimmy is angry with everyone and everything. He is angry at Alison's mother, her father and her brother. He is angry at Helena, the Sunday papers and the Church bells. His anger at Nigel, Alison's brother is mainly because he represents the government. He calls Nigel "the platitude from outer space" (24). Nigel, to Jimmy is the symbol of young British politicians who has sold the people out through his "vaguery" and it is here that his attack on the Establishment government, royalty and its apparatuses- is most pungent. According to Banham, Nigel represents all that Jimmy derides:

In fact, Nigel is being used as the symbol for Jimmy's general enemies, those he sees as smug, privileged, and what's more, successful. On the way, he manages to attack the conservative party, its candidates and supporters, politicians in general, the regular army and its officer corps, and the public schools. (20)

Again, the theme of class is strengthened by Jimmy's attack on Alison's friends and all he considered successful. To Jimmy, these people are "militant, arrogant and full of malice or vague" (44). But he is enamoured with poor workers such as Cliff, his own mother and Madeline who are sensitive and have big hearts. Only poor people fall into his classification of "good people".

Alison's mother receives a bashing from the cantankerous Jimmy. He attacks her for her role in trying to ensure that her daughter does not marry a ruffian like Jimmy. Hear him:

... there is no limit to what the middle- aged mummy will do in the holy crusade against ruffians like me. Mummy and I took one last quick look at each other, and from then on, the age of chivalry was dead. I knew that to protect her innocent young, she wouldn't hesitate to cheat, lie, bully and blackmail. (52)

Jimmy sees himself as an underdog, one who has no money, no pedigree but in spite of these, he refuses to be intimidated. He rages on calling Alison's mother "an old bitch" and that she should die. This foul, verbal attack goes on unchecked:

My God, those worms will need a good dose of salts the day they get through her! Oh, what a bellyache you've got coming to you my little wormy ones! Alison's mother is on her way! (In what he intends to be a comic declamatory voice). She will pass away, my friends, leaving a trail of worms gasping for laxatives behind her - from purgatives to purgatory. (53)

A survey of Jimmy's language above shows the use of everyday language, it is repetitive but it achieves importance by its vehemence. Look Back in Anger is an important play most especially by its use of language. The stark rhetoric and bluntness of the language is intended to shock its audience. no delicate use of words, no finesse, no tact and no delicacy. This language was new to the stage. The content of the language shows monologues, acerbic use of words, invectives, 
vituperations, insults and tirades. All of these make the audience listen and become aware of the injustices Jimmy suffers from.

Alison receives the greatest attack in the play. Being from the upper class, she becomes the butt of his misplaced anger. He attacks her verbally and physically and emotionally. He calls her Judas, a phlegm, someone that is so bloody feeble. He likens her to a "chocolate meringues - sweet and sticky on the outside and sink your teeth in it ... inside, all white, messy and disgusting ..." (49). Some of his abusive similes in the play are: "You are like a sexual manic - only with you its food" (12). "You sit there like a lump of dough" (17) and "... Oh, it's more like a zoo every day! (26). Such harsh language and invectives characterise the relationship between the couple, two individuals from different classes of the society. Jimmy humiliates, taunts, bullies and provokes her all in the bid to get her to respond physically to him. He calls her "sycophantic, phlegmatic and Pusillanimous" (21) and he provides the meaning of the last adjective as "Pusillanimous. Adjective. Wanting of firmness of mind, of small courage, having little mind, mean spirited, cowardly, timid of mind. From the Latin, Pusillus, very little, and animus, the mind" (22). And because she does not respond or talk back, he calls her "this monument to non-attachment" and all she says is "God help me, if he doesn't stop, I will go out of my mind" (22). Alison, perhaps, out of the good breeding or the well-bred nature of her class refuses to be drawn into an argument with Jimmy.

Two images of animals begin the play and ends it - "the bear and the squirrel". Jimmy and Alison play the game, he is the bear and she is the squirrel in a moment of happiness. This game assumes a larger role at the end of the play when she returns, having lost her pregnancy. It is not "fey" as Helena, Alison would want us to believe, it is their coping strategy and a way of escape. Hear Jimmy:

We'll be together in our bear's cave, and our squirrel's drey, and we'll live on honey, and nuts .... And we'll sing songs about ourselves- about warm trees and snug caves, and lying in the sun. and you'll keep those big eyes on my fur, and help me keep my claws, because I'm a bit of a soppy, scruffy sort of a bear. And I'll see that you keep that sleek bushy tail glistening as it should, because you're none too bright either, so we've to be careful. There are cruel steel traps lying about everywhere, just waiting for rather mad slightly satanic and very timid animals. Right? (96)

I have quoted this lengthy ending to the play for very clear reasons. Many critics have found it unsatisfactory. Banham says it is a "cliché of an ending" because the ending does not reflect the intensity of the emotion from the start. Jimmy has successfully roused our emotions but leaves us flat at the end.

Finally, Look Back in Anger achieves greatness because of the use of anger in the form of the play. The socio-political context of the play contributes greatly to this impact. It is mainly in its bare setting, the character and the language of the protagonist that helped to make it the important play 
it has become, even though the anger seems dated. It is a language that wakes up the audience and shocks them.

\section{Anger in Osofisan's The Chattering and the Song}

Although the plot of the play is thin, it contains very strong statements about the political life of the people. On the surface, the plot revolves around the wooing of Yajin by Sontri and the preparation for the wedding that was eventually stalled. This is what one encounters at first. However, it is more than this. The play is about the activities of a group of friends trying to effect the necessary change in the society. In the bid to achieve this, one of them, eventually reveals himself as a traitor to the cause. This group of enlightened characters came together to form the Farmers' Movement; a somewhat subversive organisation working against the chicanery of the rulers. They are angry at the situation of things in the land and so decide to join hands with the poor to transform the society. On this level, the play is a demonstration of the anger of the characters against the wicked ruler and his activities. The Farmers' Movement is actually a 'subversive' organisation whose revolutionary anger makes them the target of government's attack for they are also hunted by the government. According to Mokan, it is this group's intention to 'seize power for the farmers... arm them and proclaim a new republic' (47). They try to help the poor. It is Leje's responsibility to recruit new members into the organisation while Sontri is its songwriter.

The play opens with the courtship dance between Sontri and Yajin. They re-enact the "Iwori Otura" riddle. This riddle is on the Ifa divination tray that evokes a binary opposition. In re-enacting this riddle, the imagery of the oppressed and the oppressor is played out in the predator and prey animal imagery used:

\section{The fish swimming for life}

The hawk with the beak of steel

swooping down on the hen ... (Osofisan 1977, 1-5)

This polarised image of the oppressed and the oppressor sets the tone for the play. This image reinforced by the play-within-play employed by the playwright helps to reveal the overall effect of the play. The friends decide to give Sontri and Yajin a wedding present in form of a play. The play-within-the-play is based on the history of the Alafin Abiodun who in historical records is depicted as a benevolent king. Osofisan subverts this fact by making him a tyrannical ruler. His belief is that the benevolent ruler, if unchecked by progressive revolutionary groups can become malevolent. In fact, in an interview with Olu Obafemi, Osofisan states that even with his benevolent attitude, there was an opposition to his rule. In the play, Alafin Abiodun becomes evil. He and his friends "are fed and flourishing" and steal the lands of the poor. Alafin and his cronies are rich and their "salaries swell from the burden of poor people's taxes". His barns are full and bursting while poor people's children are on the streets begging for food. (Osofisan 1977: 42). 
Alafin supports his evil acts with his status as a divine king. He hides under the influence of being the intermediary between man and the gods.

In the play- within- the play, Sontri becomes the Alafin Abiodun who exploits his people. The traitor, Mokan, arrests him. His arrest, however, does not disrupt the activities of the Movement as we observe that Leje still carries on its activities. By this, Osofisan seems to suggest that the Movement is bigger than any single individual. Thus, the arrest of Sontri does not affect the work of the Movement.

The insensitivity and corrupt lifestyle of the King is attacked by Latoye and with the Aresa, they expose his antics of surrounding himself with the gods. Osofisan's sacrilege is to unmask the infallibility of the gods and make people aware of the fraud that the king is. In Aresa's words:

We worship Osanyin, god of secrets, but if he stands in the path of justice, we shall haul him into the stream. For all those who seek to unbalance the world, to rearrange it according to their own greed, there is only one remedy, Abiodun, Death. (Osofisan 1977:46)

Both Latoye and Aresa are vocal and are aware of their rights to speak truth to power. Latoye is seen as an underdog, a rebel and a usurper who confront Abiodun frontally. He insults the king using invectives, harsh and uncompromising language as shown above. The king resorts to magic to conquer Latoye when he could not march him words for words. Latoye, on the other hand, relies on reason as against magic. His words conscientize the guards who saw their deplorable conditions and refuse to arrest Latoye as the king has ordered. Latoye, a chief under Alafin stood up against the king's sheer irresponsibility:

Latoye: For centuries, you have shielded yourself with the gods. Slowly, you painted them in your colour, dressed them in your own cloak of terror, injustice and bloodlust ... to each of the gods, Edumare gave power and fragility so that none of them shall be a tyrant over the others and none a slave .... But in your reign Abiodun, the Elephant eats and nothing remains for the antelope! The buffalo drinks and there is drought in the land! Soldiers seize him, he is ripe for eating. (45)

Betrayal is another area where the anger of the playwright is shown. Yajin was Mokan's girl before the play begins but she is drawn to Sontri and they are to be married. Mokan's seemingly legitimate anger at Yajin's 'betrayal' or abandonment is hidden under a humorous cloak, and is left to fester into the betrayal of the larger cause of the Movement. At a certain point in the play-acting, Mokan reveals himself as a member of the State Security Police - a government force used to clamp down on resistance groups. By betraying the cause of the Farmer's Movement, Osofisan reveals that traitors and saboteurs are to be expected within a group and thus, suggests that measures must be put in place to avert their negative impact on the movement. Despite Sontri's arrest, Leje continues to recruit new members. Osofisan seems to suggest that the revolution is still on course even when the obvious leader has been arrested. 
Sontri is the most conspicuous character of the group, but in the playwright's opinion, the most quiet. Leje is its actual leader. Sontri is described in violent terms. When he first appears, Sontri is drunk as he 'lunges forward angrily, tripping, picking himself forward, crawling and swearing, towards a bottle' (1). Right from this scene to the end of the play, he is angry and abusive. Yajin describes Sontri as the hunter. His eyes are 'the colour of blood', the 'strangled scream of the people' and 'the shade of red' (4-5).

Sontri is the artist of the group as he writes all the songs of the Farmers' Movement. Yetunde is quick to remind the girls that Sontri paints but 'only with anger' for he is always angry. He is handsome but in character, Sontri is a complex individual. As pointed out by Yajin, Sontri is 'something... like a... mountain with a volcano inside...' He, like Jimmy Porter in Look Back in Anger is a not a pleasant individual to be with. As he re-enacts the Iwori- Otura riddle with Yajin in the courtship scene, the images he draws on are those of the oppressor:

'A flaming ember'

'Now I am a hawk...'

'Say I am a stag...'

As a student in college, Sontri was "the wild, untamed one, running the street with brats, garage touts, and the like, and only just managing to scale through the exams" (13). He is the one Yajin eventually falls in love with and is about to marry as the play begins. She has just broken her engagement with Mokan.

Interestingly, Sontri is a restless individual having been in the army, in politics, prison and the war. His last disappearance during the civil war has left a mark on him as observed by his friends. He is said to have grown "harder, angrier but also more concerned" and eventually, he joined the Farmers' movement (13). Yajin describes him thus,

Yajin: Far more restless. He could not settle anywhere. He joined the army and left. He tried politics and was imprisoned. Then the first coup came, and his old officers brought him out of prison....

Yajin: For over a year no one knew where he was. And then suddenly he was back....

Osofisan does not pursue the reason behind Sontri's angry behaviour. In other words, the audience is not allowed to see the motivations behind Sontri's complex personality and as pointed by Muyiwa Awodiya, this represents one fault in Osofisan's characterisation:

Osofisan is less concerned with the inner psychology of his characters and gives greater emphasis to their outward actions... Their psychological depths are not drawn. Consequently, Osofisan has not so far created the character types, which can be regarded as the authentic, individual African human types like say, the European human types- a Macbeth, a Hamlet, an Othello, etc. (119) 
Unlike Osborne's delineation where the problems of the society are implied in the troubles of the prominent characters, Osofisan treats social and economic issues on the public plane; his characters merely help to extend the issues.

Consequently, Sontri is shown mostly from outward description. It is an angry yell of "Soponnoo" that heralds his re-entry on stage. He enters 'very angry' (15) demanding to know who let the weaverbirds out of their cage. Obafemi refers to Sontri as 'the wild radical possessing an eruptive nature' (189). His language is harsh, full of invectives as he harangues Yajin and her friend. In a humorous manner, he mimics Yajin and her father, the Judge:

Ignorance! Ignorance again! No wonder you are good friends: you'll both end well. Tell me, suppose I take your pretty virgin here before her father, what do you think will be verdict? Ehn? (To Funlola, who cringes from him) Her father is a judge, you know, if you haven't heard of him, then you are not breathing. An eminent judge, known and respected from Lagos to Kaura Namoda! Esungboro! The Fearful spirit who deals out death penalties with the same ease as a wealthy man deals out fart into the air! Fortysix years on the bench! Dear father did so well, killing off the nation's bad children that, to reward him, they're going to put him on the Armed Robbery Tribunal! Ha! Ha ha! (18)

This language is reminiscent of Jimmy Porter's. Yajin may not match him word for word or anger for anger, but she is not silent like Alison, as she retorts: "Yajin: Yes Sontri, why do you stop? You know, it doesn't hurt anymore. Or are you out of words". (18) But his ravings end in humour for his anger has no malice and Yajin prays to be able to tame the fire that is in his belly.

Leje, the real leader of the Farmers' Movement, goes under many pseudonyms in order to escape police arrest. He is "Osongongon", the Farmers' leader (52). He uses drunkenness and a pronounced sense of humour as a cloak under which he hides his true identity and his anger. At the end of the play, Mokan is revealed as a traitor who sells the friends out to the government. Unlike conventional plays where individuals rise to heights by their singular efforts and the well being of the society depends on them, Osofisan pitches his tent with the collective effort of the group working together to transform society. Mokan betrays the group and Sontri is arrested but the work of organising the people continues. Hear Sontri: "The police are ignorant. What is a single man in a revolution? Once a movement begins, in the search for justice, it will run its course, with or without those who serve to spark it off ...." (The Chattering and the Song 53)

Significantly, the play is saturated with the word "anger". If we care to know the number of times that anger appears or if we could use numerical analysis, we would say that anger is specifically used in about twenty (20) instances: angrily; paints with anger; a volcanic; he grew harder and angrier, enters Sontri, very angry; controlling her anger; flaring up through anger; he is almost hoarse with anger; beside herself with rage; the anger and the gall, etc. $(1,9,11,13,15,16,17$, $18,19,22)$. These words as used could not have been placed there for their aesthetic effects but to add to the intention of the playwright in constructing the play. 


\section{Conclusion}

This paper has examined critically the representations of anger in the philosophy and dramaturgy of John Osborne and Femi Osofisan. These are two playwrights from two different continents who share the same opinion on the role of art. Significantly, they are also, in a way angry at society for not doing enough for its people. Therefore, anger stands out in the two plays selected for the study. The anger, I refer to here is not the malicious, hysterical and destructive one but one that has been tempered and tamed by artistry; cerebral or intellectual anger. A significant revelation in both plays examined is the socioeconomic problems of the post-war era in Britain and in Nigeria that provided the framework and the basis for the drama of Osborne and Osofisan. Both playwrights emerged at a time in social evolution when anger was legitimised by the social predominance of Marxist rationalism of inequality. While Osofisan is more Marxian, Osborne harbours Marxian sentiments. The protagonists of both plays share commonalities; they are restless, angry, brash and irreverent, lashing out at their partners in vituperations and verbal abuse. However, while Osofisan's anger is directed at a particular social change, Osborne's anger is not. Osborne wants a change in the socioeconomic situations of his time but does not seem to know the alternative to the situation he openly criticises.

\section{Works Cited}

Allsop, Kenneth. (1964). The Angry Decade. London: Owen.

Awodiya, Muyiwa. (1995). The Drama of Femi Osofisan. Ibadan: Kraft Books Limited. (1993). Excursions in Drama and Literature. Ibadan: Kraft Books Limited.

Banham, Martin. (1969). Osborne. Edinburgh: Oliver and Boyd.

Carter, Alan. (1969). John Osborne. Edinburgh: Oliver and Boyd.

Goldhor-Lerner, Harriet. (1985). The Dance of Anger. New York: Harper and Row Publishers.

Denilson, D. Patricia. (ed.) (1997). John Osborne: A Casebook. New York and London: Garland Publishers Inc.

Hayman, Ronald. (1970). Contemporary Playwrights: John Osborne. London: Heinemann.

Lacey, Stephen. (1995). British Realist Theatre: The New Wave in its Context 1956-1965. London and New York: Routledge.

Obafemi, Olu. (1996). Contemporary Nigerian Theatre: Cultural Heritage and Social Vision. Lagos: CBAAC.

Ogunbiyi, Yemi. (ed.) Drama and Theatre in Nigeria. Lagos: Nigeria Magazine.

Osborne, John. (1975). Look Back in Anger. London: Faber and Faber.

Osofisan, Femi. (1977). The Chattering and the Song. Ibadan: University Press.

(2001). Insidious Treasons: Drama in a Post-colonial State. Ibadan: Opon Ifa Publishers. 
Tavris, Carol. (1987). "Anger Defused” in Karen G. Duffy (ed.) Personal Growth and Behaviour. Connecticut: The Dushkin Publishing Group Inc.

Taylor, J. R. (1963). Anger and After. London: Hammondsworth.

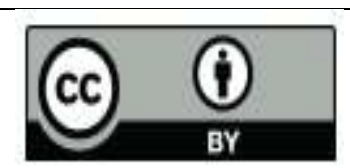

@ 2017 by the author. Licensee University of Chitral, Journal of Linguistics \& Literature, Pakistan. This article is an open access article distributed under the terms and conditions of the Creative Commons Attribution (CC BY) (http://creativecommons.org/licenses/by/4.0/). 